\title{
LIFE-TIME RISK, SCREENING AND THE COST OF CARDIOVASCULAR COMORBIDITIES IN CKD PATIENTS
}

\section{Carmine Zoccali $^{1}$, Samar Abd ElHafeez ${ }^{2}$, Evangelia Dounousi ${ }^{3}$, Rossana Anastasi ${ }^{4}$, Giovanni Tripepi $^{1}$, Francesca Mallamaci ${ }^{1,5}$}

${ }^{1}$ CNR-IFC, Clinical Epidemiology and Pathophysiology of Hypertension and Renal Diseases, Ospedali Riuniti, 89124 Reggio Calabria, Italy

${ }^{2}$ Epidemiology Department, High Institute of Public Health, Alexandria University, Alexandria. Egypt

${ }^{3}$ Department of Nephrology Medical School, University of Ioannina Ioannina, Greece

${ }^{4}$ Regione Calabria "Dipartimento Tutela della Salute e Politiche Sanitarie", Catanzaro, Italia

${ }^{5}$ Nephrology, Hypertension and Renal Transplantation Unit, Ospedali Riuniti Reggio Calabria, Italy

Corresponding Author: Carmine Zoccali, CNR-IFC, Clinical Epidemiology and Pathophysiology of Hypertension and Renal Diseases, Ospedali Riuniti, 89124 Reggio Calabria, Italy,

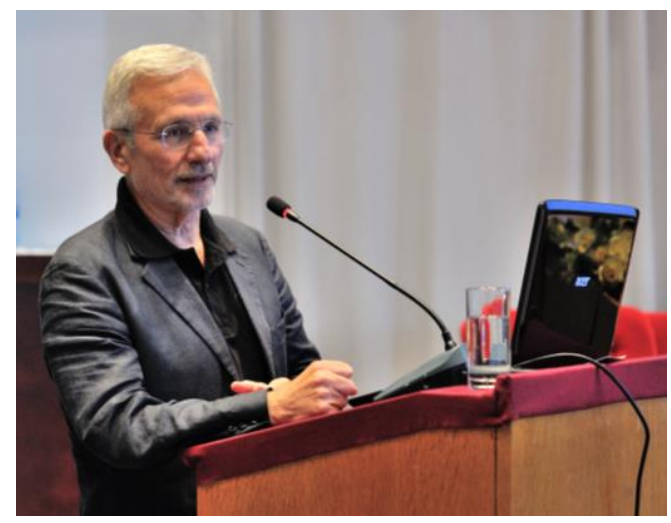

\begin{abstract}
CKD is a problem of epidemic dimension. The risk of death and cardiovascular complications in this condition is of the same order of that by myocardial infarction, which qualifies CKD as "risk equivalent". Calculations made on the basis of the epidemiological data of the MONICA-Augsburg study and analyses of the costs of myocardial infarction in a large health insurance company in Germany show that the economic burden of cardiovascular comorbidities with CKD in this country is substantial. These estimates, which may be valid also for other large member states of the European Community, represent a call for studies looking at the cost-effectiveness of preventive interventions aimed at reducing the risk for CKD and at lowering the concerning incidence rate of death and disability due to CKD-triggered cardiovascular complications in CKD patients.
\end{abstract}

Key words: Chronic Kidney Disease (CKD), cardiovascular comorbidities, life-time risk

The concept of epidemic is intimately connected to the spread of infectious diseases. However, the third millennium wave of epidemics, rather than to infectious disease, is attri- butable to a variety of chronic diseases including cancer, obesity and obesity-related diseases like type- 2 diabetes, hypertension and the resulting cardiovascular complications, myo- 
cardial infarction, heart failure, cerebrovascular and peripheral artery disease. The contribution of chronic kidney disease (CKD) to this third millennium epidemic has long been overlooked. Until 2002 there was no accepted definition of CKD and renal insufficiency was defined by a variety of thresholds based on serum creatinine rather than on estimates of glomerular function (the GFR) or renal damage (albuminuria, alterations of urine sediment, alterations in renal structure as defined by histology or imaging techniques). In 2002 Andrew Levey proposed a novel definition of CKD based on a staging system adopting GFR estimates and laboratory or imaging evidence of renal damage [1]. This staging was independent of the cause of CKD but the KDOQI guidelines adopting the same staging system emphasized the importance of establishing causality of CKD in all patients with chronic nephropaties [2]. Remarkably, this novel definition was coupled to a well-conceived action plan encompassing screening in individuals at risk, early treatment in subjects with evidence of reduced GFR and/or signs of renal damage, careful follow-up and treatment of patients with established CKD, timely referral and initiation of therapies substitutive of renal function (dialysis and transplantation) in patients who progress to final stage of kidney failure [2]. This new definition was gradually accepted worldwide and led to the discovery that CKD is much more frequent than previously realized. CKD is at least as common as diabetes and in a systematic review published in 2008 the worldwide prevalence of this disease ranged from $2.5 \%$ to $11.2 \%$ [3] being exceedingly prevalent in the old age [4]. Even more important, CKD is now per se recognized as a strong cardiovascular $(\mathrm{CV})$ risk factor [5]. Of note, recent epidemiological studies suggest that the epidemic may still be in an expanding phase, at least in the USA [6].

\section{CKD as risk equivalent}

The strong link between CKD and cardiovascular risk emerged in studies in the nineties and in the early years of the new millennium [7]. Subsequently, analyses performed in very large clinical databases provided large scale, strong evidence of the CV burden attributable to CKD [5]. The USA National Cho- lesterol Education Program Adult Treatment Panel III (ATP III) considered diabetes as a coronary heart disease risk equivalent [8]. This concept is based on the fact that the 10-year risk of coronary death or myocardial infarction (MI) in diabetic patients is equivalent to the risk associated with previous myocardial infarction, a risk exceeding the $20 \%$. More recently Tonelli et al., specifically looked at the risk for myocardial infarction and death attributable to $\mathrm{CKD}$ in a large clinical database including about 1.250.000 individuals in the Alberta region in Canada [9]. During a 4-year follow-up about $1 \%$ of subjects in this data base were hospitalized for MI. As expected, the incidence of MI was highest in individuals with previous MI (18.5 per 1000 person-years). Patients with CKD (defined as a GFR $<60$ ml.min-1.1.73 $\mathrm{m}^{2}$ ) and without diabetes and without previous MI had a lower risk (6.9 per 1000 person years) than those with previous MI but higher than those with diabetes and without CKD and without previous MI (5.4 per 1000 personyears) (Fig. 1). Furthermore, CKD patients with GFR < $45 \mathrm{ml} \cdot \mathrm{min}^{-1} .1 .73 \mathrm{~m}^{2}$ and proteinuria $>0.3 \mathrm{~g} /$ day had an incident rate of MI (12.4 per 1000 person-years) approaching that of patients with previous MI (Fig. 1). Even more concerning, the all-cause mortality risk in CKD patients (as defined by a GFR $<60$ ml.min-1.1.73 $\mathrm{m}^{2}$ ) was

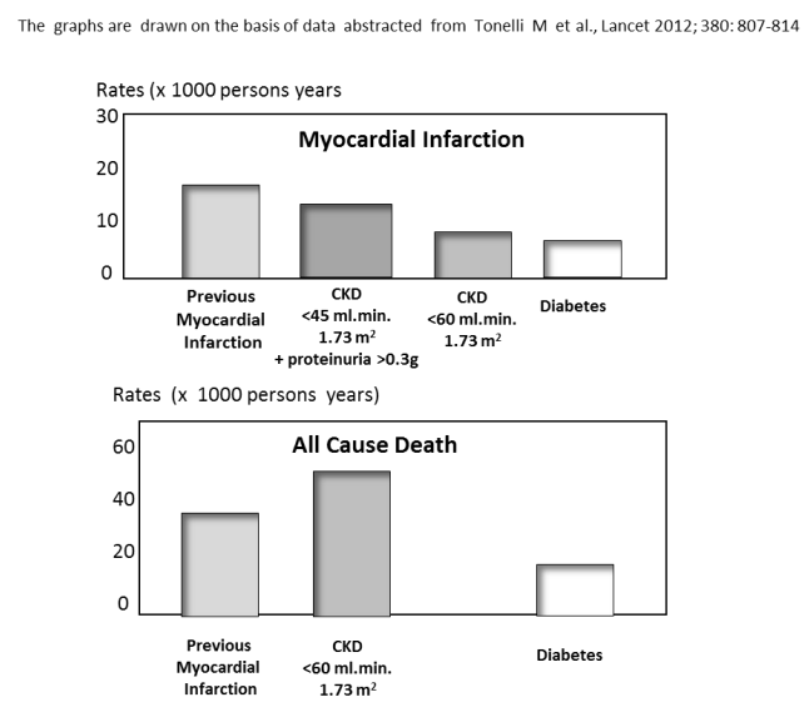

Fig. 1 -Incident risk for myocardial infarction (MI) (upper panel) and death (lower panel) in patients who had a MI and in CKD patients without previous MI and diabetes and in diabetic patients without CKD and 
previous MI. The graphs are drawn on the basis of data abstracted from Ref. 9

even higher than that of patients with previous MI. Overall these data support the concept people with CKD are at very high risk of coronary heart disease events and death and that such risk is of the same order of that registered in patients with previous MI.

\section{Life-time risk of CKD and screening policies}

Risk estimates in individual patients are important in clinical practice because allow profiling patients follow up according to the severity of disease (the predicted probability of adverse outcomes) as well as resources planning and communication with patients and heath care providers and funding institutions. Such estimates are increasingly adopted by clinical guidelines (e.g. hypertension guidelines) and constitute a fundamental element to inform screening programs, including CKD screening. In general, absolute estimates of the risk of disease are calculated for relatively short periods (e.g. 1 year risk or 5 or 10 years risk). The American College of Cardiology, American Heart Association risk calculator issued in 2013 [10] produces individual estimates of the 10 years and the lifetime risk of atherosclerotic cardiovascular disease events. Although the 10 years absolute risk for cardiovascular disease in an individual with just marginally altered $\mathrm{CV}$ risk factors may be small, if we reframe the calculation in a lifetime scale (i.e. from birth to death) the corresponding risk may be quite high. In a 40 years white male, non-diabetic, smoker, with a systolic BP of $140 \mathrm{mmHg}$, cholesterol $200 \mathrm{mg} / \mathrm{dl}$ and HDL cholesterol $30 \mathrm{mg} / \mathrm{dl}$ the 10 years risk of cardiovascular complications is $8.9 \%$ while the lifetime risk for the same events is $50 \%$.

As alluded to before, CKD is now considered as a true public priority because reduced GFR, particularly so when associated with proteinuria/albuminuria, entails a high risk for cardiovascular events and progression to end stage kidney disease. The burden of disease in terms of quality of life and health expenditures in patients who progress to the most advanced stage of CKD, stage 5 (the stage where dialysis and transplantation should be initiated) is substantial. Thus, estimates of the lifetime risk for stage $5 \mathrm{CKD}$ are of paramount relevance both for clinical management as well as for renal care planning. In 2013 investigators at the Department of Medicine, Johns Hopkins University provided estimates of the life time risk of CKD [11]. According to these estimates, in the general population at birth the overall lifetime risks of CKD stages $3 \mathrm{a}, 3 \mathrm{~b}, 4$, and 5 were $59.1 \%, 33.6 \%, 11.5 \%$, and $3.6 \%$, respectively. Thus about 1 individual out 9 ends his or her life with severe CKD (stage 4) and about 1 individual out of 28 ends his/her life on dialysis or with a kidney transplant. These concerning figures emphasize the need of prevention strategies. Prevention demands either screening, i.e. systematic, pro-active testing of all individuals at risk of disease, or early detection, i.e. testing all individuals at risk in occasion of contacts with the health system, independently of the reason why the same contact is established (for example, all individuals > 50 years who are seen by an urologist may be tested for prostate cancer). However, screening and early detection are costly undertakings and underlie not only benefits but also risks. Indeed some individuals may develop important psychological distress including anxiety and depression because of false positive findings. Therefore, screening and early detection programs need to be tested in appropriate clinical trials before being adopted on a large scale. Screening policies for prostate cancer have already been tested in clinical trials and the same is true for breast cancer. However, until now we have no such trial for CKD and it remains much debated whether or not screening for CKD is a cost effective approach. A study modelling the usefulness of screening based on microalbuminuria [12] found that mass screening at yearly intervals starting at age 50 years has a cost-effectiveness ratio of $\$ 73,000$ per quality adjusted life year (QALY) relative to no screening and $\$ 145,000$ per QALY relative to usual care (in usual care some individuals undergo some screening and treatment of CKD). Cost-effectiveness of screening improves with longer screening intervals and bi-annual screening targeting diabetic patients and hypertensive patients had a cost $<\$ 50.000$ per QALY, i.e. the threshold which is considered as cost-effective in the USA. Overall, this modelling study emphasized that targeted screening for CKD every two years may be useful. However, on the basis 
of a thorough meta-analysis of available clinical studies [13], the panel of investigators who developed the American College of Physicians (ACP) Guidelines made quite restrictive recommendations for screening [14]. Indeed, ACP recommends against screening for CKD not only in asymptomatic adults without risk factors for CKD but also in asymptomatic adults with risk factors like diabetes, Hypertension and CV disease.

\section{The cost of comorbidities in CKD}

In the lack of proper clinical trials testing the usefulness of CKD screening, it remains still uncertain whether screening programs are useful to prevent CKD and to reduce the health costs of this disease. However, detecting CKD in patients with comorbid conditions - from cardiovascular disease to infectious diseases and cancer - is important because CKD increases the risk of death and frailty in patients who are already affected other chronic conditions. The relevance of the problem in epidemiological and clinical terms is well known. Below, we will focus on the cost of comorbidities in patients with CKD. A longitudinal study aimed at evaluating the cost-effectiveness of screening in elderly people is underway in the Oxford area [15]. Herein, we will give tentative estimates of the cost of comorbidities in CKD patients derived from analyses based on the MONICA Augsburg study data [16] and on the cost of myocardial infarction in the German health system [17].

The MONICA -Augsburg study is a cohort study which is part of a multinational WHO project (Multinational MONItoring of trends and determinants in CArdiovascular disease) established worldwide in the early 1980s to monitor trends in cardiovascular diseases and to relate these trends to risk factor changes in the population over a follow up of ten years. In this study enrolling individuals in the 25-74 years range, CKD (defined as an eGFR between 59 and $15 \mathrm{ml} \cdot \mathrm{min}^{-1} .1 .73 \mathrm{~m}^{2}$ ) had a $16 \%$ prevalence. In analyses adjusting for classical risk factors, the HR for women with CKD compared to women without CKD was significantly higher for incident Myocardial Infarction (MI) [HR 1.67; 95\% confidence interval (CI) 1.07-2.61] and for cardiovascular mortality (HR 1.60; 95\% CI 1.17-2.18) and the same was true for men [incident MI (HR 1.51; 95\% CI 1.09-2.10; cardiovascular mortality HR : 1.48 ; 95\% CI 1.15-1.92) ] while in neither gender CKD did increase the risk of all-cause mortality. By direct comparison of MI events in patients with and without CKD in this cohort (194.7 vs 107 MI person.year ${ }^{-1}$, crude $\mathrm{HR}=$ 1.82), it can be calculated that CKD entails an excess number of Myocardial Infarctions equal to $8770 \mathrm{MI}$ events per million population per year. Assuming that in Germany the prevalence of CKD3-5 in individuals > 24 years is equal to that registered in Monica-Augsburg (16\%), in this country (total population 80.781.000, about $70 \%$ of whom aged $>24$ years) the number of patients with stage 3-5 CKD in the age strata > 24 years is about 9 million. By multiplying the excess of MI events in CKD patients (8770. million $^{-1}$. year $^{-1}$ ) for the whole population of CKD patients (> 24 year old) in Germany we can estimate that 78930 MI per year can be attributed to CKD. In a longitudinal study in a large German health insurance company ${ }^{17}$ the actual cost of MI during the first year after this event was about 13,000 EU. Thus, the total yearly costs of a single main $\mathrm{CV}$ comorbidity (MI) to the German health system is as high as 1,026,090,000 EU. A calculation considering the possibility that part of the cost is attri bu table to classical risk factors rather than to CKD per se, reduced the estimate to a modest extent (about 148 million EU). No suitable population data are available in the same country to make calculations of the costs of heart failure or cerebrovascular or peripheral vascular disease complications attributable to CKD. In a conservative estimate, the additional cost is likely to be at least the double of that of MI. Thus, the overall cost of cardiovascular disease events attributable to CKD in Germany may attain 3 billion/year, a very high cost which is of the same order of the total yearly average cost of the dialysis procedure in Germany (which in 2010 was about 27.000 EU per year per patient [18] in a population of about 75.000 dialysis patients). Even though these estimates pertain to one of the richest European countries, they may be grossly valid also in the large member states of the European community (also including, France, England, Italy and Spain) [19]. 
In conclusion, CKD is a problem of epidemic dimension. The risk of death and cardiovascular disease in this condition is of the same order of that by myocardial infarction, which qualifies $\mathrm{CKD}$ as a risk equivalent. The economic burden of cardiovascular comorbidities secondary to $\mathrm{CKD}$ in a rich European country like Germany is substantial. Estimates based on publicly available data in this country represent a call for studies looking at the cost-effectiveness of preventive interventions aimed at reducing the risk for CKD and at limiting the risk of death and disability attributable to CKD-triggered cardiovascular complications in CKD patients.

\section{REFERENCES}

1. Levey AS, Stevens LA, Coresh J. Conceptual model of CKD: applications and implications. Am J Kidney Dis. 2009; 53: S4-16.

2. K/DOQI clinical practice guidelines for chronic kidney disease: evaluation, classification, and stratification. Am J Kidney Dis. 2002; 39: S1-266.

3. Zhang QL, Rothenbacher D. Prevalence of chronic kidney disease in population-based studies: systematic review. BMC Public Health. 2008; 8: 117.

4. Tonelli M, Riella M. Chronic kidney disease and the ageing population. Lancet. 2014; 383: 1278-1279.

5. Gansevoort RT, Correa-Rotter R, Hemmelgarn BR et al. Chronic kidney disease and cardiovascular risk: epidemiology, mechanisms, and prevention. Lancet. 2013; 382: 339-352.

6. Grams ME, Juraschek SP, Selvin E et al. Trends in the prevalence of reduced GFR in the United States: a comparison of creatinine- and cystatin C-based estimates. Am J Kidney Dis. 2013; 62: 253-260.

7. Zoccali C. Cardiorenal risk as a new frontier of nephrology: research needs and areas for intervention. Nephrol Dial Transplant. 2002; 17 Suppl 11: 50-54.

8. Third Report of the National Cholesterol Education Program (NCEP) Expert Panel on Detection, Evaluation, and Treatment of High Blood Cholesterol in Adults (Adult Treatment Panel III) final report. Circulation. 2002; 106: 3143-3421.

9. Tonelli M, Muntner P, Lloyd A et al. Risk of coronary events in people with chronic kidney disease compared with those with diabetes: a population-level cohort study. Lancet. 2012; 380: 807-814.

10. Stone NJ, Robinson JG, Lichtenstein AH et al. 2013 ACC/AHA guideline on the treatment of blood cholesterol to reduce atherosclerotic cardiovascular risk in adults: a report of the American College of Cardiology/American Heart Association Task Force on Practice Guidelines. Circulation. 2014; 129: S1-45.

11. Grams ME, Chow EK, Segev DL, Coresh J. Lifetime incidence of CKD stages 3-5 in the United States. Am J Kidney Dis. 2013; 62: 245-252.

12. Hoerger TJ, Wittenborn JS, Segel JE et al. A health policy model of CKD: 2. The cost-effectiveness of microalbuminuria screening. Am J Kidney Dis. 2010; 55: 463-473.

13. Fink HA, Ishani A, Taylor BC et al. Screening for, monitoring, and treatment of chronic kidney disease stages 1 to 3: a systematic review for the U.S. Preventive Services Task Force and for an American College of Physicians Clinical Practice Guideline. Ann Intern Med. 2012; 156: 570-581.

14. Qaseem A, Hopkins RH, Jr., Sweet DE et al. Screening, monitoring, and treatment of stage 1 to 3 chronic kidney disease: A clinical practice guideline from the American College of Physicians. Ann Intern Med. 2013; 159: 835-847.

15. Hill NR, Lasserson D, Fatoba $S$ et al. The Oxford Renal (OxRen) cross-sectional study of chronic kidney disease in the UK. BMJ Open. 2013; 3: e004265.

16. Meisinger C, Doring A, Lowel H. Chronic kidney disease and risk of incident myocardial infarction and all-cause and cardiovascular disease mortality in middle-aged men and women from the general population. Eur Heart J. 2006; 27: 1245-1250.

17. Reinhold T, Lindig C, Willich SN, Bruggenjurgen B. The costs of myocardial infarction - a longitudinal analysis using data from a large German health insurance company. J Public Health 19, 579-586. 2011.

18. Icks A, Haastert B, Gandjour A et al. Costs of dialysis--a regional population-based analysis. Nephrol Dial Transplant. 2010; 25: 1647-1652.

19.http://epp.eurostat.ec.europa.eu/statistics_explained/i ndex.php/File:Gross_domestic_product_at_market_p rices_2011.png. Eurostat. 2014.

Резиме

\section{ЦЕЛОЖИВОТЕН РИЗИК, СКРИНИНГ И ТРОШОЦИ ЗА КАРДИОВАСКУЛАРНИТЕ КОМОРБИДИТЕТИ КАЈ ПАЦИЕНТИ СО ХРОНИЧНА БУБРЕЖНА БОЛЕСТ}

Кармине Цокали ${ }^{1}$, Самар Абд ел Хафез ${ }^{2}$, Евангелија Дунуси ${ }^{3}$, Росана Анастаси ${ }^{4}$, Џовани Трипепи ${ }^{1}$, Франческа Маламачи ${ }^{1,5}$

${ }^{1}$ CNR-IFC, Клиничка епидемиологија и патофизиологија на хипертензија и бубрежни болести, Клиничка болница, 89124,

Регион Калабрија, Италија

${ }^{2}$ Оддел за епидемиологија, Институт за јавно здравје, Универзитет во Александрија, Александрија, Египет

${ }^{3}$ Оддел за нефрологија, Медицинско училиште, Универзитет во Јанина, Јанина, Грција

${ }^{4}$ Регион Калабрија, Оддел за здравствена заштита и за здравствена политика, Катанцаро, Италија ${ }^{5}$ Оддел за нефрологија, хипертензија и трансплантација на бубрези, Клинички центар, Регион Калабрија, Италија 
Хроничната бубрежна болест (ХББ) е проблем од епидемиски размери. Ризикот од смрт и кардиоваскуларни компликации на оваа состојба е од ист степен како и кај миокардниот инфаркт, што ја квалификува ХББ како „еквивалент на ризик“. Пресметките направени врз основа на епидемиолошките податоци на студијата MONICA-Аугсбург и анализата на трошоците на миокардниот инфаркт во голема компанија за здравствено осигурување во Германија покажуваат дека економскиот товар на кардио- васкуларните коморбидитети со ХББ е значителен во оваа земја. Овие процени, што можат да важат и за други големи земји-членки на Европската заедница, претставуваат повик за студии за исплатливоста на превентивните интервенции во насока на намалување на ризикот од ХББ и за намалување на степенот на инцидентноста за смрт и инвалидитет поради кардиоваскуларни компликации поттикнати од ХББ кај пациенти со ХББ.

Клучни зборови: хронична бубрежна болест (ХББ), кардиоваскуларни коморбидитети, целоживотен ризик. 